\title{
Dynamics of Public Debt and Economic Growth in Nigeria
}

\author{
Ogu Callistus ${ }^{1^{*}} \quad$ Ojimadu Pascal $\mathrm{Kem}^{2} \quad$ Agu Anthony. $\mathrm{O}^{3}$ \\ 1.Department of Economics, Imo State University, Owerri, Nigeria \\ 2.Department of Economics, Madonna University, Nigeria \\ 3.Department of Economics, Cukwuemeka Odumegwu Ojukwu University, Anambra State Nigeria
}

\begin{abstract}
The study examined the Dynamics of Public Debt and Economic Growth in Nigeria, from 1980 to 2018. The study adopted Vector Auto Regressive Analysis in estimating the Data obtained from World Bank Development Indicator and Central Bank of Nigeria (CBN) statistical Bulletin, Annual Report and Statement of Account for the year 2018. The variables used in the study are GDP proxy for economic growth which serves as the dependent variable and External debt, Domestic debt, Government expenditure and Exchange rate form the independent variables. However, from the result it was deduced that, external debt, and domestic debt has a negative impact on economic growth in Nigeria. This is shown by the negative coefficient of EXDBT, and DDEBT. However, government expenditure and exchange rate has a positive impact on economic growth in Nigeria, and jointly, all the variables were significant as seen with the probability statistics. The VAR, estimates was able to show the extent of dynamics between public debt and economic growth especially when debts are disaggregated into external and domestic debt. It was concluded that, while domestic debts sign negatively with Nigeria's gross domestic product, external debts sign negatively with it. The results contradict a-priori expectation of positive relationships based on theoretical postulation of the advantageous effects of leverage both at corporate and national levels, however, the results might probably have emanated from the fact that external debts are often associated with stringent repayment terms. They also embody other trade conditionality's which may turn out to be counterproductive and inimical to the growth of less developed economies. However, it was recommended that, Nigeria should concentrate on inward financing of her economic growth by utilizing mostly, domestic debts
\end{abstract}

Keywords: Public Debt, External Debt, Domestic Debt, Economic Growth

DOI: $10.7176 / \mathrm{JESD} / 10-24-03$

Publication date: December $31^{\text {st }} 2019$

\section{Introduction}

Debt, arguably, remains one of the major economic challenges facing governments in low income countries due to their persistence budget deficit and this has continued to attract the attention of international financial institutions, and bilateral lenders. Udeh (2016) notes that this has brought about the adoption of several initiatives capable of alleviating the debt burden which continues to hinder the growth prospects of most Highly Indebted Poor Countries (HIPCs) economies. These initiatives range from debt rescheduling to outright cancellation.

Nigeria external debts dated back to pre- independence era when it acquired its first loan of twenty eight (28) million US dollars from World Bank, to finance the construction of railway. Ayadi and Ayadi (2016) reported that by 1960 , the Nigeria's external debt profile had risen to 150 million US dollar. The quest for developmental plans and the need to finance the flamboyant lifestyle of government leaders in Nigeria surged up the country's external debt to 1 billion US dollar by 1971. The increase in external debt alarmingly continued which was however due to fall in oil price in 1978 and sharp decline in the balance of payment. Debt Management Office (2000) noted that Nigeria obtained her first jumbo loan of 1 billion US dollar from International Capital Market (ICM) in 1978 summing the external debt to 2.2 billion US dollars. The states in the country joined in contracting loans from foreign creditors which gave rise to Nigeria external loan of about N17.3 billion in 1986, a situation that compelled the nation to adopt the Structural Adjustment Programme (SAP) in 1986, which was packaged by International Monetary Fund (IMF) as a means to revamping the nation's economy (Ayadi \& Ayadi, 2016). By 2005, Nigeria indebtedness to foreign creditors had gone to a very escalating amount of 30 billion US dollar, which servicing cost was generally considered as unsustainable. This scenario attracted debt relief from Paris/London Club in 2006, thereby making Nigeria debt burden and profile lighter. In view of the above, Nigeria started to re accumulate and record upward move in external debt from 2008 in a bid to foster the required economic growth and a support to fiscal deficits. National Bureau Statistics (2017) reports that Nigeria's debt to foreign creditors in 2016 stood at 15.05 billion US dollar and N14.06 trillion to domestic creditors. The usage of heavy inflow of cash via external debt to double up economic growth and development of Nigeria is rightly in accordance with Keynesian Theory of capital accumulation as a catalyst for economic growth. Contrarily, Campbell (2009) noted that accumulating debt is accumulating risk by increasing claims on future unrealized income. It becomes paramount to ascertain how far the heavy external debt of Nigerian government has actually helped to foster economic growth as propelled by Keynesian theory, or has the debt accumulation exposed the country to great danger as expressed by Campbell (2009). Therefore this study is set to find out the extent of impact of public debt on economic growth in Nigeria. 
However, Events in the recent past in Nigeria have led to increasing concerns about the possible adverse consequences of the size of domestic debt as well as the possible consequential effects of its reduction on private sector investment, the pricing of petroleum products (the mainstay of the economy), unemployment, corruption, inflation and indeed the living standard of the citizenry; irrespective of its continued use by government to finance projects. For instance, N1.95trillion out of the approved N9.12 trillion 2018 national budget will be financed by domestic debt (Appropriation Act, 2018). The concern is borne out of the experiences of countries like Mexico, Argentina, Portugal, and Greece between 1980s and 2012. The fears range from threats to financial stability to political pressures and inability of financial institutions to withstand recessions and other similar adversities.

Despite the huge amount of debts which the country has continued to incur over the years, with the aim of achieving economic growth and development, high unemployment, poverty, and low standard of living is still prevalent in the country, as observed by Aiyedogbon and Ohwojasa (2012) and Nwagwu (2014). The inability of Nigeria to effectively meet her debt obligations has adverse effect on the economy, as interests arrears accumulate over the years, thereby creating a much greater debt burden on the nation resulting in a greater percent of her revenue being spent on debt service arrears.

\section{Empirical Review}

Monogbe (2016) empirically examined data pooled from 1981 to 2014 as an instrument for investigating intergenerational effect of external debt on economic performance of Nigeria. He found that total money supply, multilateral creditors and bilateral creditors which are proxy for external debt have positive and significant relationship with economic growth in Nigeria.

Ugwuegbe, Okafor and Azino (2016) used annual time series data to investigate the effect of external borrowing and foreign aid on economic growth in Nigeria from 1980 to 2013. They used GDP as a parameter for economic growth and external debt, foreign aid, exchange rate regime and foreign reserve as the exogenous variables. Econometric techniques of Ordinary Least Square (OLS) multiple regression, Augmented Dickey Fuller (ADF), Johansen Co-integration, Error Correction Method (ECM) were applied. The results show that external debt has a positive and significant effect on economic growth, foreign aid has positive and insignificant effect on economic growth in Nigeria.

Ugwu and Nzewi (2016) evaluated the effect of external debt on economic growth parameters in Nigeria. They employed ex post facto research design and the result show that positive relationship exists among external debt and economic growth parameter (GDP, exchange rate, capital expenditure). They conclude that small external debt accumulation stimulates the economy while huge debt s negative impact on the economy.

Adeniran, Azeez and Aremu (2016) empirically examined the impact of external debt on economic growth in Nigeria with data from 1980 to 2014, while applying Vector Error Correction model found that external debt service payment do negatively impact significantly on Nigeria economic growth.

\section{Gap in Literature}

Summarily, the reviewed literature disclosed that most of the authors had used many parameters to proxy public debt but all the studies reviewed in Nigeria, were carried out using ordinary least square (OLS) approach and Johansson cointegration test, and Error correction with scanty work on Vector Auto Regression (VAR) approach of analyzing the impact of public debt on economic growth, like, Adeniran, Azeez and Aremu (2016), Ugwu and Nzewi (2016), Ugwuegbe, Okafor and Azino (2016), Monogbe (2016) among others with very few applying other econometrics method of analysis. In this study, Vector Auto Regression (VAR) approach and causality techniques are applied to examine the influence and direction of causality between public debt and Economic growth in Nigeria. Hence, the justification of this study.

3. Research Methodology

3.1 Model Specification

$\mathrm{GDP}=\mathrm{F}(\mathrm{EXTD}, \mathrm{DDEBT}, \mathrm{GEXP}, \mathrm{EXR})$

Where,

GDP $=$ Gross Domestic Product

EXTD $=$ External Debt

DDEBT $=$ Domestic Debt

GEXP = Government Expenditure

$\mathrm{EXR}=$ Exchange Rate

The mathematical form of the model

\subsection{Diagnostic Test of the Model}

Diagnostic test of the model were carried out using, unit root test, co integration, error correction, VAR, coefficient of multiple determination, $\mathrm{R}^{2}$ analysis of variance and Durbin Watson statistics 


\subsubsection{Unit Root Test}

To fully explore the data generating process, we first examined the time series properties of model variables using the Augmented Dickey- Fuller test.

The ADF test regression equations with constant are:

$$
\Delta Y_{T}=\alpha_{0}+\alpha_{1} Y_{T-1}+\sum_{j=1}^{k} a_{j} \Delta Y_{T-1}+\varepsilon_{T} \cdots
$$

where $\Delta$ is the first difference operator $\varepsilon_{\mathrm{T}}$ is random error term that is iid $\mathrm{k}=$ no of lagged differences $\mathrm{Y}$ $=$ the variable. The unit root test is then carried out under the null hypothesis $\alpha=0$ against the alternative hypothesis

of $\alpha<0$. Once a value for the test statistics $A D F_{\tau}=\frac{\alpha}{S E(\alpha)}$

(3) _is computed we shall compare it

with the relevant critical value for the Dickey-Fuller Test. If the test statistic is greater (in absolute value) than the critical value at $5 \%$ or $1 \%$ level of significance, then the null hypothesis of $\alpha=0$ is rejected and no unit root is present. If the variables are non-stationary at level form and integrated of the same order, this implies evidence of co-integration in the model. The co-integration equation is stated in equation 7

\subsubsection{Co integrated equation}

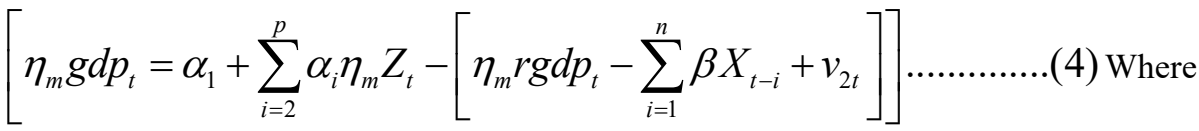

$\left[\eta_{m} g d p_{t}-\sum_{i=1} \beta X_{t-i}\right]$ is the linear combination of the non co integrated vectors,

$\mathrm{X}$ is a vector of the non co integration variables. The individual influence of the co integrated variables can only be separated with an error correction mechanism through an error correction model as shown below.

\subsubsection{The Error Correction Model}

Equation $\left[\eta_{m} g d p_{t}=\alpha_{1}+\sum_{i=2}^{p} \alpha_{i} \eta_{m} Z_{t}-\left(\lambda E C M_{t-i}+v_{4 t}\right)\right]$

Where $-\lambda e c m$ is the error correction mechanism, $-\lambda$ is the magnitude of error corrected each period specified in its a priori form so as to restore $\eta_{m} K F_{t}$ to equilibrium

Also the optimum lag length of the was determined using the multivariate versions of information criteria of Akaike's Information Criteria (AIC) and Schwarz's Bayesian Information Criteria (SBIC).

\subsubsection{Vector Autoregressive Model}

The study employed vector autoregressive (VAR) model of Sims (1980), which is transformed into the VECM that is if the variables are cointegrated. This will aid the estimation of the short-run dynamic relationship and account for the speed of adjustment in the short and long run.

The Mathematical form of VAR:

$$
Y_{t}=A_{1} Y_{t-1}+A_{2} Y_{t-2}+\ldots . .+A_{p} Y_{t-p}+B X_{t}+\mathrm{e}_{t}
$$

where $Y_{t}$ is a $K$ vector endogenous variable, $X_{t}$ is a $d$ vector of exogenous variables $A_{1} \ldots, A_{p}$ and $B$ are matrices of coefficients to be estimated, and $\varepsilon_{t}$ is a vector of innovations that may be contemporaneously correlated with other but are uncorrelated with their own lagged values and uncorrelated with exogenous variables.

$$
\begin{aligned}
& \text { VAR form of the model } \\
& \begin{array}{l}
G D P_{t}=\alpha_{0}+\alpha_{1} \sum_{J=1}^{K} G D P_{t-1}+\alpha_{2} \sum_{J=1}^{K} E X T D_{t-1}+\alpha_{3} \sum_{J=1}^{K} D D E B T_{t-1}+\alpha_{4} \sum_{J=1}^{K} G E X P_{t-1}+\alpha_{5} \sum_{J=1}^{K} E X R_{t-1}+\varepsilon_{1 t}(7) \\
E X T D_{t}=\alpha_{0}+\alpha_{1} \sum_{J=1}^{K} E X T D_{t-1}+\alpha_{2} \sum_{J=1}^{K} G D P_{t-1}+\alpha_{3} \sum_{J=1}^{K} D D E B T_{t-1}+\alpha_{4} \sum_{J=1}^{K} G E X P_{t-1}+\alpha_{5} \sum_{J=1}^{K} E X R_{t-1}+\varepsilon_{2 t}(8) \\
D D E B T_{t}=\alpha_{0}+\alpha_{1} \sum_{J=1}^{K} D D E B T_{t-1}+\alpha_{2} \sum_{J=1}^{K} G D P_{t-1}+\alpha_{3} \sum_{J=1}^{K} E X T D_{t-1}+\alpha_{4} \sum_{J=1}^{K} G E X P_{t-1}+\alpha_{5} \sum_{J=1}^{K} E X R_{t-1}+\varepsilon_{3 t}(9) \\
G E X P_{t}=\alpha_{0}+\alpha_{1} \sum_{J=1}^{K} G E X P_{t-1}+\alpha_{2} \sum_{J=1}^{K} G D P_{t-1}+\alpha_{3} \sum_{J=1}^{K} E X T D_{t-1}+\alpha_{4} \sum_{J=1}^{K} D D E B T_{t-1}+\alpha_{5} \sum_{J=1}^{K} E X R_{t-1}+\varepsilon_{4 t}(10)
\end{array}
\end{aligned}
$$




$$
E X R_{t}=\alpha_{0}+\alpha_{1} \sum_{J=1}^{K} E X R_{t-1}+\alpha_{2} \sum_{J=1}^{K} G D P_{t-1}+\alpha_{3} \sum_{J=1}^{K} E X T D_{t-1}+\alpha_{4} \sum_{J=1}^{K} D D E B T_{t-1}+\alpha_{5} \sum_{J=1}^{K} G E X P_{t-1}+\varepsilon_{5 t}(11)
$$

where $\mathrm{j}$ is the lag length, $\mathrm{K}$ is the maximum distributed lag length $\alpha_{0}$ is the constant terms $\varepsilon_{t}$ is independent and identically distributed error term.

In matrix form, the above can be compactly specified as in equation (14)

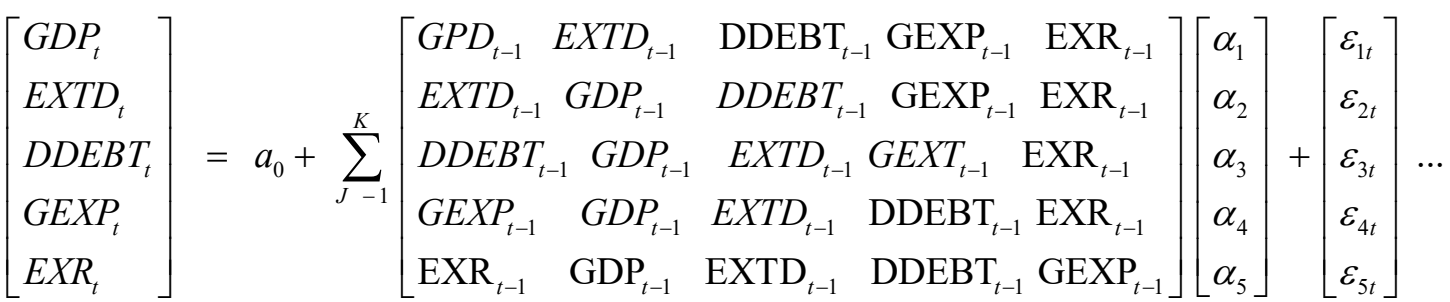

\subsubsection{Justification of the Model}

The choice of a VAR model is made on the basis of its superiority to other models that are highly vulnerable to simultaneity bias. It has the ability to test for weak exogeneity and parameter restrictions. It also assumes that there is no apriori direction of causality among the variables. VAR models offer a way of analyzing the dynamic relationship between choice variables of the study. It helps to account for the delayed response with parsimonious lag structure (Agenor et al., 2005). When a direct interpretation of the estimated individual variables is difficult, a joint F-test on the lagged variables could be used to provide the information regarding the impact of the anticipated portion of the independent variables. Thus an important feature of VAR model is its use in estimating residuals called VAR innovations and it obviates a decision as to what contemporaneous variables are exogenous with only lagged variables on the right hand side. It therefore recognizes all variables as dependent variable Greenwood and Jovanovic (1990).

\section{Data Presentation and Analysis}

\section{Diagnostic Tests of the Model}

Diagnostic test of the model were carried out using the coefficient of multiple determination, Analysis of variance and Durbin Watson statistics. The relevant results are stated in Table 4.1 below

Table 4.1: Diagnostic Test Results

\begin{tabular}{|l|l|}
\hline TEST STATISTIC & VALUE \\
\hline $\mathrm{R}^{2}$ & 0.958422 \\
\hline Adjust $\mathrm{R}^{2}$ & 0.953531 \\
\hline F- statistics & 195.9353 \\
\hline Prob(F Statistic) & 0.000000 \\
\hline D.W & 0.694510 \\
\hline
\end{tabular}

\section{Source: Regression Result 2019}

Explanatory Power of the Model

$\mathrm{R}^{2}$, the coefficient of multiple determinations was used to test the explanatory power of the model and the goodness of fit. From the result $\mathrm{R}^{2}$ adjusted for degree of freedom is 0.958422 (Table 4.1 ). This indicates that $96 \%$ of systematic variations in the dependent variable are explained by changes in the independent variables in the model. This level of explanatory power was considered satisfactory.

\section{Overall Significance of the Model}

To test the overall significance of the regression, analysis of variance (ANOVA) is 195.9353 and prob (F-Statistic) is 0.000000 . Testing the null hypothesis that the coefficients are equal to zero at $5 \%$ level of significance, we reject the null hypothesis since the probability f-statistics is less than 0.05 in each case. We therefore conclude that the independent variables have significant impact on the dependent variable in the model.

\section{Impact of Public Debt on Economic Growth}

Table 4.2 Regression Output

\begin{tabular}{|l|l|l|l|l|}
\hline Variable & Coefficient & Std. Error & t-Statistic & Prob. \\
\hline C & $1.56 \mathrm{E}+13$ & $1.36 \mathrm{E}+12$ & 11.42096 & 0.0000 \\
\hline EXDBT & $-3.44 \mathrm{E}+09$ & $8.05 \mathrm{E}+08$ & -4.269081 & 0.0001 \\
\hline DDEBT & $-3.34 \mathrm{E}+09$ & $1.16 \mathrm{E}+09$ & -2.885738 & 0.0067 \\
\hline GEXP & $1.03 \mathrm{E}+10$ & $2.27 \mathrm{E}+09$ & 4.517847 & 0.0001 \\
\hline EXR & $2.04 \mathrm{E}+11$ & $3.36 \mathrm{E}+10$ & 6.076835 & 0.0000 \\
\hline
\end{tabular}

SOURCE: AUTHOR'S ANALYSIS 2019

The result of the regression can be summarized in equation from as follows: 


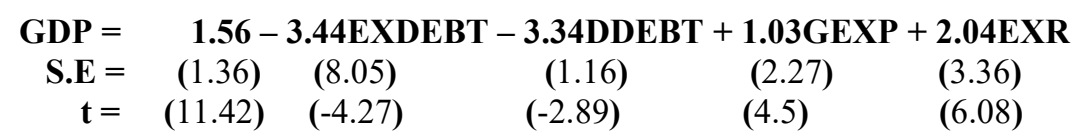

From the regression result stated above (Table 4.2) external debt, and domestic debt has a negative impact on economic growth in Nigeria. This is shown by the negative coefficient of EXDBT, and DDEBT. In addition, for each unit change in EXDBT, and DDEBT (-3.44), and (-3.34) respectively of such change is transmitted to economic growth in the Country. However, government expenditure and exchange rate has a positive impact on economic growth in Nigeria, all these is seen in the coefficient of the variables in table 4.2.

\section{Test Of Significance (Hypotheses Testing)}

The significance test was tested for the significance of the independent variables at $5 \%$ level using t-prob, t-statistic and the coefficients of the independent variables. The rule applied was: if significant probability is greater than the prescribed level of $5 \%$ or 0.05 we accept the null hypothesis otherwise we reject the null hypothesis when significant probability is less than 0.05 . The regression results are shown in the Table below.

Table 4.3: Regression

\begin{tabular}{|l|l|l|l|l|}
\hline Variable & Coefficient & Std. Error & t-Statistic & Prob. \\
\hline C & $1.56 \mathrm{E}+13$ & $1.36 \mathrm{E}+12$ & 11.42096 & 0.0000 \\
\hline EXDBT & $-3.44 \mathrm{E}+09$ & $8.05 \mathrm{E}+08$ & -4.269081 & 0.0001 \\
\hline DDEBT & $-3.34 \mathrm{E}+09$ & $1.16 \mathrm{E}+09$ & -2.885738 & 0.0067 \\
\hline GEXP & $1.03 \mathrm{E}+10$ & $2.27 \mathrm{E}+09$ & 4.517847 & 0.0001 \\
\hline EXR & $2.04 \mathrm{E}+11$ & $3.36 \mathrm{E}+10$ & 6.076835 & 0.0000 \\
\hline
\end{tabular}

SOURCE: AUTHOR'S ANALYSIS 2019

To test the significant, the significant probability of external debt, domestic debt, government expenditure, and exchange rate, from the regression result (Table 4.3) are $(0.0001),(0.0067),(0.0001)$, and $(0.0000)$ respectively. Following the rule we reject the null hypothesis in all since significant probability is less than 0.05 and conclude that external debt, domestic debt, government expenditure, and exchange rate have significant impact on economic growth in Nigeria.

\section{Unit Root Test}

A unit root test (ADF) was conducted to ascertain whether the variables in the model are stationary. This is necessary as it helps to avoid spurious regression results.

The summary of Unit Root Tests (ADF) results using E-views software is detailed in the table below:

Table 4.4: Summary of ADF test results at $1 \%, 5 \%$ and $10 \%$ critical value

\begin{tabular}{|c|c|c|c|c|c|c|c|}
\hline \multirow[t]{2}{*}{ Variable } & \multirow{2}{*}{$\begin{array}{l}\text { Order of } \\
\text { Integration }\end{array}$} & \multirow{2}{*}{$\begin{array}{l}\text { ADF Test } \\
\text { Statistics }\end{array}$} & \multicolumn{3}{|c|}{ ADF Critical Value } & \multirow{2}{*}{$\begin{array}{l}\text { Lag } \\
\text { Length }\end{array}$} & \multirow[t]{2}{*}{ Decision } \\
\hline & & & $1 \%$ & $5 \%$ & $10 \%$ & & \\
\hline GDP & $I \sim(1)$ & -4.699222 & -3.621023 & -2.943427 & -2.610263 & $\mathbf{0}$ & Reject $\mathrm{H}_{0}$ \\
\hline EXDBT & $\mathrm{I} \sim(2)$ & -6.094206 & -3.632900 & -2.948404 & -2.612874 & 1 & Reject $\mathrm{H}_{0}$ \\
\hline DDEBT & $I \sim(2)$ & -5.904809 & -3.639407 & -2.951125 & -2.614300 & 2 & Reject $\mathrm{H}_{0}$ \\
\hline GEXP & $I \sim(2)$ & -4.884254 & -3.661661 & -2.960411 & -2.619160 & 5 & Reject $\mathrm{H}_{0}$ \\
\hline EXR & $I \sim(1)$ & -4.302862 & -3.626784 & -2.945842 & -2.611531 & 1 & Reject $\mathrm{H}_{0}$ \\
\hline
\end{tabular}

Source: research output 2019

From table 1 above, observe that the variables are not stationary at level form but became stationary after first difference and second differencing which implies that the variables (EXDBT, DDEBT, and GEXP) are integrated of order one $(\mathrm{I} \sim(2))$ whereas GDP and EXR was integrated of order zero $(\mathrm{I} \sim(1))$ stationary at level form

\subsection{Co-integration Test Result}

A necessary but not sufficient condition for co-integrating test is that each of the variables be integrated of the same order. The Johansen co-integration test uses two statistics test namely: the trace test and the likelihood eigenvalue test. The first row in each of the table test the hypotheses of no co-integrating relation, the second row test the hypothesis of one co-integrating relation and so on, against the alternative of full rank of co-integration. The results are presented in table 4.5 below. 
TABLE 4.5 Johansen co-integration test

Date: 09/08/19 Time: $12: 37$

Sample (adjusted): 19832018

Included observations: 36 after adjustments

Trend assumption: Linear deterministic trend

Series: GDP EXDBT DDEBT GEXP EXR

Lags interval (in first differences): 1 to 2

Unrestricted Cointegration Rank Test (Trace)

\begin{tabular}{lllll}
\hline \hline $\begin{array}{l}\text { Hypothesized } \\
\text { No. of CE }(\mathrm{s})\end{array}$ & Eigenvalue & $\begin{array}{l}\text { Trace } \\
\text { Statistic }\end{array}$ & $\begin{array}{l}0.05 \\
\text { Critical Value }\end{array}$ & Prob.** \\
\hline \hline None ${ }^{*}$ & 0.854517 & 135.9900 & 69.81889 & 0.0000 \\
At most 1 $*$ & 0.575353 & 66.59307 & 47.85613 & 0.0004 \\
At most 2 & 0.486111 & 35.75913 & 29.79707 & 0.0091 \\
At most 3 & 0.271406 & 11.79217 & 15.49471 & 0.1672 \\
At most 4 & 0.010863 & 0.393197 & 3.841466 & 0.5306
\end{tabular}

Source: Author's Analysis

The Johansson co-integration test result revealed that the trace and maxi-eigen value has three co-integrating factor, which necessitates the conclusion that a long-run co-movement relationship exists among the variables employed in this study.

\section{Short-Run Estimate}

The Error Correction Mechanism (ECM) was used to obtain the short-run estimate at 5\% level of significance. The result from the ECM is presented in table 4.5 below.

TABLE 4.6 CORRECTION MECHANISMS

\begin{tabular}{|l|l|l|}
\hline VARIABLE & COEFFICIENT & T-PROBABILITY \\
\hline ECM(-1) & -0.013157 & 0.8915 \\
\hline
\end{tabular}

Source: Author's Analysis, 2019.

From the result in TABLE 4.7 since the coefficient of the $\operatorname{ECM}(-1)$ which is negative we say that there is convergence.

\section{Selection of Optimal Lag}

In order to carry out vector autoregression estimation, the choice of lag length is vital. There is various lag length criteria, among them are; Sequential modified LR test statistic with each test at 5\%, the Final prediction error (FPE), Akaike information criterion (AIC), Schwarz information criterion (SC) and the Hannan-Quinn information criterion (HQ). However each of these has different penalty factors. For the purpose of this study, we therefore limit the selection to Akaike information criterion (AIC) and Schwarz information criterion (SC). The Akaike Information Criterion (AIC) and Scharwz Information Criterion are employed because according to Yahaya, Salisu and Umar (2015) they are the most popular used selection criteria for models. From the result, the two criteria revealed 3 optimal number of lag to be used for the VAR analysis. The result is presented below in table 4.7 below Table 4.7 Lag Length Criteria

\begin{tabular}{|c|c|c|c|c|c|c|}
\hline Lag & $\log L$ & LR & FPE & AIC & $\mathrm{SC}$ & HQ \\
\hline 0 & -2199.464 & NA & $1.06 \mathrm{e}+47$ & 122.4702 & 122.6901 & 122.5470 \\
\hline 1 & -1968.754 & 384.5156 & $1.17 \mathrm{e}+42$ & 111.0419 & 112.3615 & 111.5025 \\
\hline 2 & -1927.924 & 56.70797 & $5.30 \mathrm{e}+41$ & 110.1625 & 112.5817 & 111.0069 \\
\hline 3 & -1860.986 & $74.37556^{*}$ & $6.51 \mathrm{e}+40 *$ & $107.8326^{*}$ & $111.3515^{*}$ & $109.0608 *$ \\
\hline \multicolumn{7}{|c|}{$\begin{array}{l}\text { * indicates lag order selected by the criterion } \\
\text { LR: sequential modified LR test statistic (each test at } 5 \% \text { level) } \\
\text { FPE: Final prediction error } \\
\text { AIC: Akaike information criterion } \\
\text { SC: Schwarz information criterion } \\
\text { HQ: Hannan-Quinn information criterion }\end{array}$} \\
\hline
\end{tabular}

Source: Author's Analysis 


\subsection{VAR Test Estimates}

From the result below in table 4.8 below, it was revealed that GDP to itself in the $1^{\text {st }}$ period is positive while in the second period is negative, external debt to GDP in the first period is negative while at the second period is positive, domestic debt to GDP in the first period is negative while at the second period was positive, government expenditure to GDP in the first period is positive while at the second period is negative, and lastly exchange rate to GDP in the first period is negative while at the second period was positive.

\section{Table 4.8 VAR RESULT}

Vector Autoregression Estimates

Date: 09/08/19 Time: 12:06

Sample (adjusted): 19822018

Included observations: 37 after adjustments

Standard errors in ( ) \& t-statistics in [ ]

\begin{tabular}{|c|c|c|c|c|c|}
\hline & GDP & EXDBT & DDEBT & GEXP & EXR \\
\hline GDP(-1) & $\begin{array}{c}1.286716 \\
(0.23857) \\
{[5.39345]}\end{array}$ & $\begin{array}{c}-1.08 \mathrm{E}-10 \\
(6.0 \mathrm{E}-11) \\
{[-1.81307]}\end{array}$ & $\begin{array}{c}-1.48 \mathrm{E}-11 \\
(2.8 \mathrm{E}-11) \\
{[-0.53325]}\end{array}$ & $\begin{array}{c}7.42 \mathrm{E}-11 \\
(2.4 \mathrm{E}-11) \\
{[3.13174]}\end{array}$ & $\begin{array}{r}-3.50 \mathrm{E}-13 \\
(1.0 \mathrm{E}-12) \\
{[-0.33510]}\end{array}$ \\
\hline $\operatorname{GDP}(-2)$ & $\begin{array}{r}-0.411623 \\
(0.23875) \\
{[-1.72404]}\end{array}$ & $\begin{array}{c}1.14 \mathrm{E}-10 \\
(6.0 \mathrm{E}-11) \\
{[1.90892]}\end{array}$ & $\begin{array}{c}6.16 \mathrm{E}-11 \\
(2.8 \mathrm{E}-11) \\
{[2.21461]}\end{array}$ & $\begin{array}{c}-8.06 \mathrm{E}-11 \\
(2.4 \mathrm{E}-11) \\
{[-3.40051]}\end{array}$ & $\begin{array}{c}2.85 \mathrm{E}-12 \\
(1.0 \mathrm{E}-12) \\
{[2.72116]}\end{array}$ \\
\hline $\begin{array}{l}\text { R-squared } \\
\text { Adj. R-squared } \\
\text { Sum sq. resids } \\
\text { S.E. equation } \\
\text { F-statistic } \\
\text { Log likelihood } \\
\text { Akaike AIC } \\
\text { Schwarz SC } \\
\text { Mean dependent } \\
\text { S.D. dependent }\end{array}$ & $\begin{array}{c}0.993217 \\
0.990608 \\
1.33 \mathrm{E}+26 \\
2.26 \mathrm{E}+12 \\
380.7204 \\
-1098.530 \\
59.97461 \\
60.45353 \\
3.97 \mathrm{E}+13 \\
2.33 \mathrm{E}+13\end{array}$ & $\begin{array}{l}0.934009 \\
0.908628 \\
8304076 . \\
565.1438 \\
36.79944 \\
-280.4455 \\
15.75381 \\
16.23273 \\
1546.100 \\
1869.617\end{array}$ & $\begin{array}{l}0.996430 \\
0.995057 \\
1807253 . \\
263.6470 \\
725.7039 \\
-252.2341 \\
14.22887 \\
14.70779 \\
2644.260 \\
3749.971\end{array}$ & $\begin{array}{l}0.992597 \\
0.989750 \\
1311040 . \\
224.5543 \\
348.6103 \\
-246.2959 \\
13.90789 \\
14.38681 \\
1761.311 \\
2217.960\end{array}$ & $\begin{array}{r}0.989830 \\
0.985918 \\
2557.338 \\
9.917618 \\
253.0485 \\
-130.8631 \\
7.668276 \\
8.147197 \\
97.60374 \\
83.57526\end{array}$ \\
\hline \multicolumn{6}{|c|}{$\begin{array}{l}\text { The impulse test revealed that the GDP of the economy respond positively to itself throughout the periods. Between } \\
\text { the } 1 \text { st and } 5.8 \text { periods, GDP response to external debt was negative, but from the } 6^{\text {th }} \text { period it became positive } \\
\text { Furthermore, GDP to domestic debt fluctuates also even though it was positive from the beginning of the period } \\
\text { GDP to government expenditure was negative from the first period to the } 2.5 \text { period and was positive from } 2.6 \\
\text { period to } 6.5 \text { period till it turn negative. Between } 1 \text { st and } 4 \text { th, period GDP negatively respond to Exchange rate } \\
\text { but negatively relate again in the } 7^{\text {th }} \text { period. }\end{array}$} \\
\hline
\end{tabular}


Figure 1 Impulse Response Graph

Response of GDP to GDP
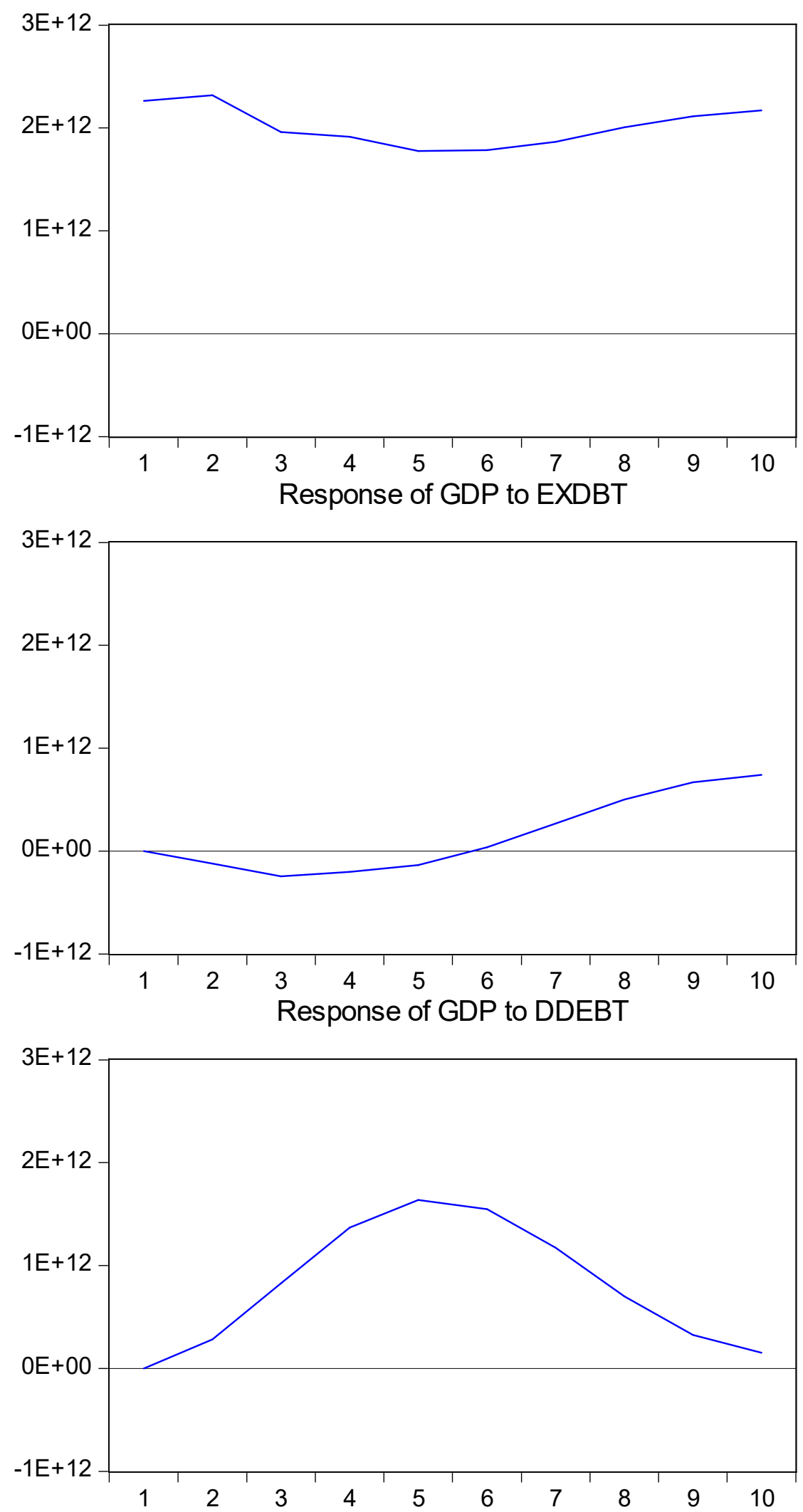


\section{Response of GDP to GEXP}

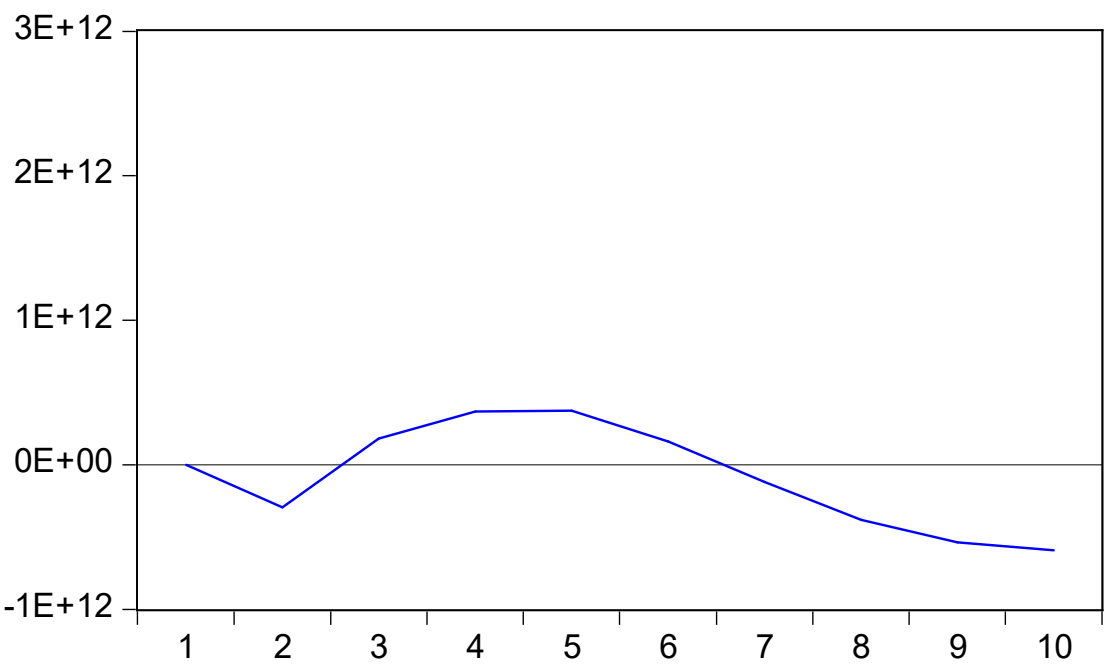

Response of GDP to EXR

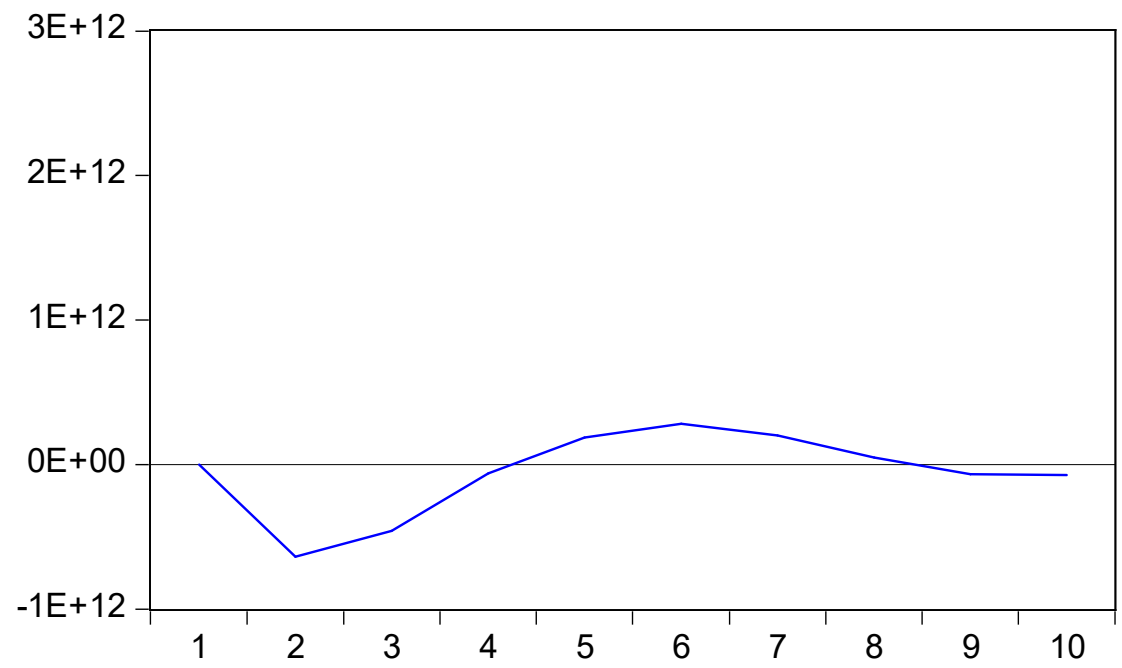

Variance Decomposition Test

Table 4.9 Variance Decomposition of GDP

\begin{tabular}{|l|l|l|l|l|l|l|}
\hline Period & S.E. & GDP & EXDBT & DDEBT & GEXP & EXR \\
\hline 1 & $2.26 \mathrm{E}+12$ & 100.0000 & 0.000000 & 0.000000 & 0.000000 & 0.000000 \\
\hline 2 & $3.33 \mathrm{E}+12$ & 94.68206 & 0.133812 & 0.717251 & 0.792333 & 3.674539 \\
\hline 3 & $3.99 \mathrm{E}+12$ & 90.07130 & 0.467178 & 4.823258 & 0.763051 & 3.875210 \\
\hline 4 & $4.65 \mathrm{E}+12$ & 83.19728 & 0.533583 & 12.21389 & 1.187970 & 2.867281 \\
\hline 5 & $5.26 \mathrm{E}+12$ & 76.45616 & 0.484277 & 19.25218 & 1.437872 & 2.369513 \\
\hline 6 & $5.77 \mathrm{E}+12$ & 72.95796 & 0.405740 & 23.16134 & 1.269412 & 2.205544 \\
\hline 7 & $6.19 \mathrm{E}+12$ & 72.56180 & 0.536864 & 23.73287 & 1.142122 & 2.026339 \\
\hline 8 & $6.57 \mathrm{E}+12$ & 73.62147 & 1.056681 & 22.16909 & 1.350997 & 1.801757 \\
\hline 9 & $6.97 \mathrm{E}+12$ & 74.76551 & 1.859911 & 19.96216 & 1.798280 & 1.614140 \\
\hline 10 & $7.36 \mathrm{E}+12$ & 75.68843 & 2.676188 & 17.92726 & 2.252710 & 1.455408 \\
\hline
\end{tabular}

Source: Author's Analysis 
Table 4.10 Variance Decomposition of EXDBT

\begin{tabular}{|l|l|l|l|l|l|l|}
\hline Period & S.E. & GDP & EXDBT & DDEBT & GEXP & EXR \\
\hline 1 & 565.1438 & 10.07774 & 89.92226 & 0.000000 & 0.000000 & 0.000000 \\
\hline 2 & 938.0002 & 25.70188 & 73.90911 & 0.003530 & 0.242433 & 0.143051 \\
\hline 3 & 1160.224 & 33.12056 & 63.20745 & 0.003698 & 1.326588 & 2.341707 \\
\hline 4 & 1276.497 & 34.65759 & 56.20008 & 0.449476 & 4.230654 & 4.462206 \\
\hline 6 & 1357.878 & 31.64987 & 50.76507 & 3.844697 & 9.474856 & 4.265503 \\
\hline 7 & 1467.940 & 27.17728 & 43.94193 & 10.91083 & 13.61686 & 4.353097 \\
\hline 8 & 1580.885 & 24.34177 & 38.15886 & 16.47310 & 14.40379 & 6.622471 \\
\hline 9 & 1635.349 & 23.73188 & 35.68084 & 17.69250 & 13.76377 & 9.131010 \\
\hline 10 & 1653.273 & 23.71437 & 35.10158 & 17.39773 & 13.74386 & 10.04245 \\
\hline
\end{tabular}

Source: Author's Analysis

Variance Decomposition of DDEBT

Table 4.11

\begin{tabular}{|l|l|l|l|l|l|l|}
\hline Period & S.E. & GDP & EXDBT & DDEBT & GEXP & EXR \\
\hline 1 & 263.6470 & 20.82135 & 0.004464 & 79.17418 & 0.000000 & 0.000000 \\
\hline 2 & 435.8431 & 19.92398 & 0.409807 & 77.64119 & 2.016265 & 0.008765 \\
\hline 3 & 516.1085 & 14.52969 & 0.514097 & 82.35231 & 1.470180 & 1.133721 \\
\hline 4 & 580.8799 & 12.55036 & 0.892658 & 77.62298 & 1.167478 & 7.766520 \\
\hline 5 & 671.3616 & 15.16455 & 1.484350 & 66.63727 & 1.065179 & 15.64865 \\
\hline 6 & 796.9891 & 18.33331 & 2.714715 & 58.20324 & 2.255736 & 18.49300 \\
\hline 7 & 964.4158 & 19.57760 & 4.304353 & 55.73724 & 4.597615 & 15.78319 \\
\hline 8 & 1166.571 & 19.04622 & 5.579954 & 57.06462 & 6.661629 & 11.64758 \\
\hline 9 & 1373.386 & 18.66859 & 6.122870 & 59.03754 & 7.576725 & 8.594272 \\
\hline 10 & 1554.428 & 19.40239 & 6.050844 & 60.12613 & 7.628930 & 6.791712 \\
\hline
\end{tabular}

Source: Author's Analysis

Table 4.12 Variance Decomposition of GEXP

\begin{tabular}{|l|l|l|l|l|l|l|}
\hline Period & S.E. & GDP & EXDBT & DDEBT & GEXP & EXR \\
\hline 1 & 224.5543 & 0.136207 & 0.252309 & 33.65392 & 65.95757 & 0.000000 \\
\hline 2 & 332.2883 & 3.748769 & 0.116350 & 63.42907 & 32.59886 & 0.106953 \\
\hline 4 & 444.3425 & 2.404725 & 1.860241 & 72.10215 & 23.57264 & 0.060239 \\
\hline 5 & 518.4256 & 3.366424 & 2.441016 & 75.90726 & 18.19827 & 0.087030 \\
\hline 6 & 564.8610 & 6.296530 & 2.803023 & 74.71060 & 15.58039 & 0.609458 \\
\hline 7 & 610.1063 & 12.78483 & 2.604005 & 68.76920 & 13.37615 & 2.465823 \\
\hline 8 & 659.8670 & 19.20313 & 2.341287 & 62.23678 & 11.60389 & 4.614904 \\
\hline 9 & 716.0485 & 24.31409 & 2.163008 & 57.79360 & 10.42530 & 5.303993 \\
\hline 10 & 780.7852 & 27.07382 & 2.166584 & 56.20306 & 9.788133 & 4.768405 \\
\hline
\end{tabular}

Source: Author's Analysis

Table 4.13 Variance Decomposition of EXR

\begin{tabular}{|l|l|l|l|l|l|l|}
\hline Period & S.E. & GDP & EXDBT & DDEBT & GEXP & EXR \\
\hline 1 & 9.917618 & 0.015770 & 8.921609 & 42.79902 & 1.160969 & 47.10264 \\
\hline 2 & 13.79117 & 1.761357 & 12.31194 & 40.27957 & 1.157780 & 44.48935 \\
\hline 3 & 15.97529 & 1.315855 & 19.73185 & 30.34624 & 10.73712 & 37.86893 \\
\hline 4 & 19.31567 & 2.536768 & 23.11477 & 27.24627 & 21.12229 & 25.97991 \\
\hline 5 & 23.86582 & 6.055223 & 21.51898 & 29.66313 & 23.53962 & 19.22305 \\
\hline 6 & 27.05161 & 9.698956 & 19.73698 & 30.59993 & 22.37158 & 17.59255 \\
\hline 7 & 28.31498 & 13.48459 & 18.76563 & 29.30137 & 21.27719 & 17.17122 \\
\hline 8 & 28.93087 & 16.70064 & 17.98020 & 28.42786 & 20.38746 & 16.50384 \\
\hline 9 & 29.97486 & 18.86425 & 16.88920 & 29.69163 & 19.06263 & 15.49229 \\
\hline 10 & 31.26066 & 20.82628 & 15.66885 & 31.53528 & 17.55556 & 14.41402 \\
\hline
\end{tabular}

Source: Author's Analysis

It was revealed that the variations in the GDP to itself is $100 \%$ in the 1 st quarter, but reduces in the 5 th and 
10th period to $73 \%$ and $76 \%$ respectively. External debt was in the 1 st period captures about $90 \%$ changes in economic growth; $51 \%$ in the 5 th period and $34 \%$ in the 10 th period. Domestic debt in the 1 st period accounts for $79 \%$ changes in the growth of the country, in the 5th and 10th period, an increase in variations captured by the variable is $67 \%$ and $60 \%$ respectively. In the 1 st period of the variations in the GDP through government expenditure, $66 \%$ was accounted for, while in the 5 th and 10th period the percentage of variations falls heavily to $16 \%$ and $9 \%$ respectively. The contribution of the exchange rate in the country was observed to be very low. In the 1 st period, $47 \%$ of the variations in the GDP was captured, while in the $5^{\text {th }}$ and 10 th period, $19 \%$ and $14 \%$ was captured

\section{Discussion of Findings, Conclusion, and recommendations}

The study examined the dynamics of public debt and Economic growth in Nigeria, from 1980 to 2018. The study adopted Vector Auto Regressive Analysis in estimating the Data obtained from World Bank Development Indicator and Central Bank of Nigeria (CBN) statistical Bulletin, Annual Report and Statement of Account for the year 2018. The variables used in the study are GDP proxy for economic growth which serves as the dependent variable and External debt, Domestic debt, Government expenditure and Exchange rate form the independent variables. However, from the result it was deduced that, external debt, and domestic debt has a negative impact on economic growth in Nigeria. This is shown by the negative coefficient of EXDBT, and DDEBT. In addition, for each unit change in EXDBT, and DDEBT (-3.44), and (-3.34) respectively of such change is transmitted to economic growth in the Country. However, government expenditure and exchange rate has a positive impact on economic growth in Nigeria, all these is seen in the coefficient of the variables in table, and all the variables were significant as seen with the probability statistics. The VAR, estimates was able to show the extent of dynamics between public debt and economic growth especially when debts are disaggregated into external and domestic debt. It was concluded that, it is vital to note that while domestic debts sign negatively with Nigeria's gross domestic product, external debts sign negatively with it. The results contradict a-priori expectation of positive relationships based on theoretical postulation of the advantageous effects of leverage both at corporate and national levels, however, the results might probably have emanated from the fact that external debts are often associated with stringent repayment terms. They also embody other trade conditionalities which may turnout to be counterproductive and inimical to the growth of less developed economies. However, the results of this study have shown that changes in both domestic and external debts either in their aggregated or structural forms are valuable in predicting partially, the dynamics in Nigeria's gross domestic product and hence, economic performance. However, it was recommended that, Nigeria should concentrate on inward financing of her economic growth by utilizing mostly, domestic debts. And External debt should only be utilized by Nigeria, either as a matter of last resort or to fund a project with high foreign exchange content

\section{References}

Adeniran, A.O., Azeez, M.I., \&Aremu, J.A. (2016).External debt and economic growth in Nigeria: A Vector AutoRegression (VAR) Approach. International Journal of Management and Commerce Innovations, 4(1), 706 714.

Ayadi, F.S.,\&Ayadi, F.O. (2016). The Impact of external debt on economic growth: A comparative study of Nigeria and South Africa.Journal of Sustainable Development in Africa, 10(3), 234 - 264.

Aiyedogbon, J. O. and Ohwojaso, B. O. (2012) "Poverty and youth unemployment in Nigeria". International Journal of Business and Social Science

Monogbe, T.G. (2016). Intergenerational effect of external debt on performance of the Nigeria economy. $N G$ Journal of Social Development, 5(2), 51-65.

Nwagwu, E. J. (2014). “Unemployment and Poverty in Nigeria: A link to National Insecurity” European Centre for Research Training and Development UK.:www.ea-journals.org.

Udeh, S.N., Ugwu, J.I., \&Onwuka, I.O. (2016). External debt and economic growth: The Nigeria experience. European Journal of Accounting, Auditing and Finance Research,4(2), 33-48.

Ugwu, J.I., \&Nzewi, U.C. (2016).An evaluation of the effect of external debt on economic growth indices in Nigeria. A paper presented in 2016 International conference of Faculty of Management Sciences, NnamdiAzikiwe University, Awka, at the University auditorium from 8th-10thNovermber. Theme: Managing Diversification for Sustainable Development in sub-Sahara Africa.

Ugwuegbe, S.U., Okafor, I.G.,\&Akarogbe, C.A. (2016).Effect of external borrowing and foreign aid on economic growth in Nigeria.International Journal of Academic Research in Business and Social Sciences, 6(4), 155175. 